\title{
PENERAPAN STRATEGI KOOPERATIF-KOLABORATIF DALAM PEMBELAJARAN MENULIS SURAT RESMI SISWA SMA
}

\author{
Kusubakti Andajani \\ Fakultas Sastra Universitas Negeri Malang \\ e-mail: kusubaktiandajani@yahoo.com
}

\begin{abstract}
This study aimed to describe the improvement of business letter writing skills through the cooperative-collaborative strategy. The design employed the action research procedure by Kemmis and McTaggart (1988), consisting of plan, action, observation, and reflection. The subjects were Year XII students of the Language Program of SMAN 2 Batu. The data were collected through tests, observations, field notes, and interviews and analyzed by means of the qualitative descriptive technique. The results showed that business letter writing was one topic that the students could not master well. They wrote letters based on those the teacher presented because they did not know much about effective sentences, diction, and spelling. Therefore, they did not have creativity in writing letters. This problem was solved using the cooperative-collaborative strategy. Through this strategy, the students were more motivated to learn and the quality of the learning outcomes could be enhanced to the maximum.
\end{abstract}

Keywords: cooperative-collaborative strategy, business letters

\section{PENDAHULUAN}

Menulis merupakan suatu tindakan penyampaian pesan dengan mengunakan bahasa tulis sebagai alat atau medianya. Pada era global, ketrampilan menulis memiliki fungsi yang sangat strategis dalam kehidupan sehari-hari. Hampir setiap aktivitas manusia memerlukan kegiatan menulis. Untuk dapat melakukan pergaulan dengan masyarakat secara efektif, seseorang perlu memiliki kemampuan menulis. Menulis merupakan wahana untuk mengembangkan diri. Dengan memiliki kemampuan menulis, seseorang dapat berperan dalam mempengaruhi dan menentukan kehidupan bermasyarakat atau dalam komunikasi sosialnya. Dengan memiliki kemampuan menulis pula, segala gagasan, kreativitas, dan perasaan dapat disampaikan kepada orang lain dalam ruang dan waktu yang tidak terbatas. Mengingat pentingnya fungsi menulis tersebut, perlu kiranya siswa dibekali kemampuan menulis sebaik mungkin.

Badudu (1998) berpendapat bahwa ketrampilan menulis siswa di Indonesia masih rendah. Hal ini dapat ditengarai oleh rendahnya frekuensi kegiatan menulis siswa, buruknya kualitas karya tulis siswa, rendahnya antusiasme siswa dalam mengikuti kegiatan pembelajaran BI pada umumnya dan menulis pada khususnya, serta rendahnya kreativitas belajar siswa pada saat kegiatan pembelajaran menulis berlangsung.

Keberhasilan pembelajaran menulis di sekolah ditentukan oleh enam faktor, yaitu kurikulum, guru, siswa, administrasi, fasilitas penunjang, dan lingkungan belajar. Dalam hal ini, mutu pendidikan berkaitan erat dengan guru. Kunci keberhasilan pelaksanaan pembelajaran sangat ditentukan oleh guru. Iklim belajar di kelas yang dipimpin 
oleh guru sangat menentukan arah dan keberhasilan belajar para siswa. Jika siswa dalam kelas dikelola oleh guru yang profesional maka situasi kelas dan hasil belajarnya dapat diharapkan menjadi baik. Sebaliknya, jika kelas ditangani guru yang kurang profesional maka tujuan pembelajaran yang telah ditetapkan akan sulit dicapai.

Menurut Tompkins \& Hoskisson (1991), rendahnya ketrampilan menulis siswa bukan disebabkan oleh keterbatasan atau ketidakmampuan siswa dalam menulis, melainkan lebih disebabkan oleh pendekatan yang digunakan guru tidak mampu mengarahkan siswa untuk dapat belajar menulis dengan baik. Materi yang disajikan guru kurang menantang siswa untuk berkreativitas. Selain itu, metode yang digunakan guru sering kurang tepat sehingga pembelajaran menulis menjadi kurang menarik perhatian siswa.

Smith (dalam Suparno \& Yunus, 2002) menjelaskan bahwa pengalaman belajar menulis yang dialami siswa di sekolah tidak terlepas dari kondisi guru yang membelajarkan menulis. Pada umumnya guru tidak trampil menulis. Guru juga tidak dipersiapkan untuk mumpuni mengajarkan ketrampilan menulis kepada siswa. Program yang dirancang guru masih belum berpedoman pada aspek-aspek yang perlu diperhatikan dan dikerjakan siswa pada setiap tahap menulis. Akibatnya, guru tidak optimal dalam membimbing siswa untuk berpikir mengenai apa yang akan ditulis dan bagaimana cara menuangkan gagasan dalam bentuk tulisan. Siswa pun tidak optimal dalam mengaplikasikan kemampuan menulisnya.

Abdurrahman (dalam Gipayana, 2004) mengungkapkan bahwa strategi pembelajaran yang keliru, pengelolaan kegiatan belajar yang tidak mampu membangkitkan motivasi belajar siswa, dan pemberian tugas untuk reinforce- ment yang tidak tepat justru mematikan motivasi belajar menulis siswa. Faktor lingkungan belajar siswa (termasuk di antaranya guru) memiliki andil dalam menentukan keberhasilan pembelajaran. Lingkungan yang mendukung akan berpengaruh terhadap minat, kemampuan, dan kebiasaan menulis siswa. Pembinaan secara terus-menerus dan menyenangkan akan membawa siswa pada minat dan kebiasaan yang diinginkan. Cara-cara yang menyenangkan merupakan pendorong utama siswa untuk belajar menulis. Belajar sesuatu dengan cara mudah dan bermanfaat dapat membangkitkan minat dan motivasi siswa.

Salah satu keterampilan menulis yang perlu dikuasai siswa SMA adalah menulis korespondensi atau surat menyurat resmi. Dalam banyak hal, surat menjadi alat komunikasi tertulis yang sangat penting, baik bagi perorangan, organisasi pemerintah, bisnis, maupun kemasyarakatan. Siswa SMA tidak akan merasa kesulitan apabila diminta membuat surat yang bersifat pribadi dan informal. Kerumitan baru dirasakan apabila mereka diminta menyusun surat resmi, karena surat-surat tersebut menuntut digunakannya format-format tertentu dengan disertai kepantasan dan ketepatan penggunaan bahasa yang tertentu pula.

Menulis surat resmi merupakan satu materi yang tidak dikuasai siswa secara baik. Pada umumnya siswa menyusun surat berdasarkan contoh yang diberikan guru. Bahasa yang digunakan, komponen surat, dan bentuk surat ditulis siswa sama persis dengan contoh tersebut. Biasanya siswa hanya menggantikan isi komponen surat contoh dengan isi komponen surat yang sesuai dengan soal, misalnya tanggal surat, alamat surat, atau pengirim surat. Berdasarkan wawancara dengan beberapa siswa SMA, diketahui bahwa hal terse- 
but disebabkan oleh kurangnya penguasaan siswa terhadap kalimat efektif, diksi, dan ejaan. Ketidakpahaman siswa terhadap tiga komponen tersebut berdampak pada tidak adanya kreativitas siswa dalam menyusun surat.

Berdasarkan wawancara dengan sejumlah guru Bahasa Indonesia di SMA, pada dasarnya guru telah melaksanakan prosedur pembelajaran sebagaimana mestinya. Terlebih dulu guru menyampaikan materi tentang kalimat efektif, diksi, dan ejaan kepada siswa. Kemudian, setelah memberikan beberapa contoh surat resmi, guru meminta siswa mengaplikasikan pengetahuan tentang kalimat efektif, diksi, dan ejaan dalam wujud surat resmi.

Paparan di atas ditunjang oleh pengamatan awal yang peneliti lakukan terhadap surat-surat resmi siswa kelas III SMA Negeri 2 Batu, tampak sebagian besar siswa di antaranya tidak mampu menulis surat resmi secara baik dan benar. Hasil identifikasi terhadap surat-surat tersebut menunjukkan bahwa kelemahan umum yang dialami siswa terjadi pada: (1) penggunaan format surat yang tidak baku dengan indikasi tidak dikemukakannya secara tepat dan lengkap beberapa bagian surat, (2) penggunaan bahasa yang berbelit-belit dengan susunan kalimat yang tidak efektif, (3) penggunaan pilihan kata yang kurang cermat sehingga sering terjadi kesenjangan antara maksud surat dengan isi surat, serta (4) terjadi kesalahan penggunaan ejaan, termasuk di antaranya penggunaan tanda baca yang tidak pada tempatnya.

Pada hakikatnya, ada kesamaan komponen pembangun yang mendasar antara surat resmi satu dengan surat resmi yang lain. Komponen yang dimaksud meliputi format surat dan bahasa surat. Ada beberapa format surat yang bisa dipilih siswa dalam menulis surat resmi, yang mana masing-masing format menuntut adanya bagian-bagian surat dalam formasi-formasi tertentu. Hal yang sering dilakukan siswa adalah mencampuradukkan penggunaan satu format surat dengan format surat yang lain sehingga kebakuan surat tidak dapat dipertahankan. Dalam kaitannya dengan bahasa surat, hal yang sering dilakukan siswa adalah menggunakan kalimat secara berbelit-belit, tidak logis, dan tidak lengkap unsur-unsur pembentuknya (SPOK-nya). Selain itu, siswa kurang cermat dalam melakukan pemilihan kata sehingga sering terjadi kesenjangan antara maksud surat dengan isi surat. Dalam hal ejaan, siswa banyak melakukan kesalahan dalam menuliskan huruf kapital dan penggunaan tanda baca.

Selama ini guru cenderung mengatasi kelemahan-kelemahan siswa tersebut dengan melakukan semacam analisis terhadap kesalahan-kesalahan yang dibuat siswa dalam surat resmi yang mereka susun. Guru berasumsi bahwa siswa akan belajar dari kesalahan-kesalahan yang pernah dibuat sebelumnya dan tidak akan mengulangi kesalahan-kesalahan yang sama pada penyusunan surat-surat resmi yang lain.

Tindakan guru tersebut didasarkan pada pola pikir kaum behavioris yang melihat pengetahuan sebagai kumpulan pasif dari subjek dan objek yang diperkuat oleh lingkungannya, dan melihat mengajar sebagai suatu upaya mengatur lingkungan agar dapat membantu siswa dalam belajar. Dapat diambil suatu pengertian bahwa kaum behavioris menempatkan kegiatan belajar mengajar lebih sebagai suatu proses pengajaran, bukan pembelajaran. Dalam hal ini gurulah yang aktif mendulang siswa dengan berbagai informasi pelajaran. Strategi mengajar seperti di atas ditengarai berpotensi membentuk siswa menjadi individu yang pasif. Kreativitas siswa tidak berkembang, kemampuan 
bernalar siswa tidak tersalurkan, pengetahuan siswa tidak tergali, sehingga kemandirian siswa dalam belajar pun menjadi hilang.

Kiranya, strategi kooperatif-kolaboratif menjadi satu alternatif strategi yang tepat untuk digunakan dalam kegiatan pembelajaran surat resmi bagi siswa SMA. Strategi kooperatif-kolaboratif merupakan salah satu bentuk strategi pembelajaran yang didasarkan pada filsafat konstruktivisme, yang mengorientasikan belajar pada siswa (student-centered learning), bukan studentcentered teaching ataupun teacher-centered teaching. Dengan strategi kooperatif-kolaboratif, siswa dapat secara bersamasama berusaha memahami karakteristik isi dan bentuk surat resmi yang dicontohkan guru sekaligus menganalisis surat resmi yang telah mereka buat sebelumnya melalui serangkaian kegiatan diskusi, baik antara siswa dengan siswa maupun antara siswa dengan guru. Dari hasil diskusi tersebut diperoleh suatu kesepakatan makna sebagai wujud konstruksi baru, yang kemudian menjadi pengetahuan baru bagi siswa.

Fenomena rendahnya kemampuan siswa dalam menulis surat resmi terjadi pada siswa kelas III SMAN 2 Batu. Hal ini dirasa cukup merisaukan. Penulisan surat yang kurang jelas akan menghambat arus informasi, sehingga sering terjadi salah tafsir terhadap isi surat. Karenanya, perlu dikaji lebih lanjut upaya pemecahan masalahnya sekaligus upaya meningkatkan kemampuan siswa dalam menulis surat resmi. Penelitian yang perlu dilakukan untuk mengkaji fenomena semacam ini adalah penelitian tindakan kelas (classroom action research). Dengan demikian, penelitian ini bertujuan meningkatkan kemampuan menulis surat resmi melalui strategi kooperatif-kolaboratif siswa kelas III SMA.

\section{METODE}

Penelitian ini dilaksanakan untuk mengatasi masalah pembelajaran, yaitu rendahnya kemampuan siswa dalam menulis surat resmi. Tindakan yang dilakukan untuk meningkatkan kemampuan menulis surat resmi ini adalah strategi kooperatif-kolaboratif.

Selama penelitian berlangsung, dibutuhkan keterlibatan guru yang bekerja secara kolaboratif. Paparan tersebut menyiratkan bahwa (1) terdapat permasalahan faktual dalam pembelajaran, yaitu kemampuan siswa dalam menulis surat resmi masih rendah, (2) ada tindakan yang dilakukan untuk memperbaiki permasalahan tersebut, yaitu penggunaan strategi kooperatif-kolaboratif, serta (3) terjadi kolaborasi antara peneliti dengan guru selama penelitian berlangsung. Berdasarkan ciri-ciri tersebut, penelitian ini merupakan penelitian tindakan kelas (classroom action research) dengan satu kasus dalam satu situs (Suyanto, 2002).

Model rancangan penelitian tindakan kelas yang digunakan dalam penelitian ini adalah model rancangan yang dikembangkan oleh Kemmis dan McTaggart (1992). Model ini mengikuti alur yang terdiri dari empat komponen pokok, yaitu perencanaan, pelaksanaan tindakan, pengamatan, dan refleksi. Pada tahap awal dilakukan studi pendahuluan dan pengamatan terhadap proses pembelajaran menulis surat resmi untuk mengidentifikasi permasalahan yang ada di kelas. Berdasarkan hasil pengamatan tersebut disusun Rencana Tindak Siklus I yang diwujudkan dalam bentuk Satuan Pembelajaran. Selanjutnya, Rencana Tindak Siklus I itu diaplikasikan dalam Pelaksanaan Tindakan Pembelajaran yang nyata di kelas dengan melibatkan keberadaan guru sebagai tenaga pelaksananya. Sementara itu, dilakukan pengamatan secara 
langsung terhadap proses pembelajaran tersebut sambil mencatat hal-hal yang sekiranya perlu mendapat perlakuan baru. Hasil pengamatan direfleksikan dan dijadikan dasar bagi penyusunan rencana tndakan Siklus II yang juga diwujudkan dalam bentuk Satuan Pembelajaran. Selanjutnya, rencana tindakan Siklus II tersebut diaplikasikan dalam pelaksanaan tindakan pembelajaran yang nyata di kelas dengan tetap melibatkan keberadaan guru sebagai tenaga pelaksananya.

Data dalam penelitian ini berupa data tindakan, data tuturan, dan data hasil penilaian. Data tindakan merupakan data nonverbal berupa informasi tindakan pembelajaran yang diberikan oleh guru dan aktivitas siswa berkaitan dengan pemberian tindakan tersebut. Data tuturan merupakan data verbal yang berupa tuturan lisan dan tertulis yang diperoleh sebelum, selama, dan setelah tindakan berlangsung. Data hasil penilaian diperoleh melalui kajian terhadap proses dan produk tindakan di tiap tahap pembelajaran. Proses tindakan pada setiap tahap pembelajaran dikaji melalui dinamika kerjasama kelompok dan perkembangan siswa dalam kelompok, sedangkan produk tindakan pada setiap tahap pembelajaran dikaji melalui perkembangan kemampuan siswa dalam menulis surat resmi dengan strategi kooperatif-kolaboratif. Tiga jenis data yang bersumber dari siswa dan guru tersebut menggambarkan proses dan produk tindakan pembelajaran menulis surat resmi dengan strategi kooperatif-kolaboratif. Adapun sumber data dalam penelitian ini adalah siswa kelas III Bidang Bahasa dari SMAN 2 Batu dan guru Bahasa Indonesia di sekolah tersebut.

Proses pembelajaran dinilai berdasarkan dinamika kelompok. Karenanya, rambu-rambu analisis yang digunakan dalam menganalisis proses pembelajaran disesuaikan dengan aspek-aspek yang membangun kelompok, yang selanjutnya ditetapkan sebagai indikator proses pembelajaran menulis surat resmi dengan strategi kooperatifkolaboratif. Indikator yang dimaksud meliputi (1) keseriusan, (2) keresponsifan, (3) kerja sama, dan (4) ketepatan waktu.

\section{HASIL DAN PEMBAHASAN}

Penelitian dilakukan dalam tiga siklus dengan tujuan meningkatkan kemampuan siswa kelas III SMA dalam menulis surat resmi melalui strategi kooperatif-kolaboratif. Masing-masing siklus dilakukan dalam dua kali pertemuan.

Pada siklus I, keterlibatan guru dalam kegiatan pembelajaran di kelas dibatasi. Intensitas pembelajaran diorientasikan pada kemandirian siswa. Hal ini dilakukan mengingat siswa yang diajar adalah siswa kelas 12 (SMA kelas III). Bimbingan guru terhadap siswa hanya berupa arahan-arahan mengenai prosedur pembelajaran yang disampaikan pada awal kegiatan. Di luar itu guru hanya memberi bimbingan terbatas pada kelompok-kelompok yang meminta bantuan selama pelaksanaan diskusi tersebut. Pembentukan kelompok diserahkan sepenuhnya kepada siswa. Dari 32 siswa yang hadir, terbentuk 4 kelompok dengan masing-masing kelompok beranggotakan 8 siswa. Dasar pembagian siswa menjadi 4 kelompok adalah jumlah aspek dalam surat-menyurat yang perlu dikaji oleh siswa, yaitu format surat, ejaan, pilihan kata, dan kalimat efektif. Kelompok-kelompok tersebut dinamakan Kelompok 1, Kelompok 2, Kelompok 3, dan Kelompok 4.

Diketahui bahwa kelompok yang terbentuk cenderung homogen dalam hal kualitas akademik. Para siswa berkelompok sesuai dengan kedekatan mereka dalam berteman sehari-hari, yang 
pada umumnya memiliki kebiasaan sama. Sementara, kebiasaan yang sama berpengaruh pada kesetaraan prestasi belajar atau kemampuan akademik siswa. Akibatnya, ada kecenderungan siswa dengan kemampuan akademik tinggi berkelompok dengan siswa lain dengan kemampuan akademik yang tinggi pula, siswa dengan kemampuan akademik menengah juga cenderung berkelompok dengan siswa lain dengan kemampuan akademik menengah, sedangkan siswa dengan kemampuan akademik rendah pun cenderung berkelompok dengan siswa lain dengan kemampuan akademik rendah. Namun, pola pengelompokan homogen yang demikian tidak berlaku secara mutlak. Artinya, dalam jumlah terbatas, terjadi juga pembauran siswa dengan kemampuan akademik yang berbeda.

Setelah guru menyampaikan tiga contoh surat lamaran pekerjaan dan siswa mencermati dengan seksama aspek-aspek pembangun yang terdapat dalam tiga surat lamaran pekerjaan tersebut, selanjutnya guru meminta siswa pada tiap kelompok membagi diri menjadi 4 kelompok baru, yang anggotanya diambil dari 2 siswa kelompok awal, sehingga setiap kelompok beranggotakan 8 siswa yang berbeda dengan kelompok awal. Pembentukan kelompok baru ini juga sepenuhnya diserahkan kepada siswa, tanpa pertimbangan akademis apapun. Masing-masing kelompok baru mendapat tugas mendalami satu aspek dalam penulisan surat resmi. Karenanya, kelompok-kelompok baru tersebut mendapat sebutan Kelompok Format Surat, Kelompok Ejaan, Kelompok Pemilihan Kata, dan Kelompok Kalimat Efektif.

Kelompok baru yang terbentuk ternyata lebih heterogen daripada kelompok awal. Meski masih dalam komposisi yang belum berimbang dan tidak beraturan, setiap kelompok se- lalu beranggotakan siswa lengkap dari tiga tingkat akademik, yaitu berkemampuan akademik tinggi, menengah, dan rendah. Seperti misalnya, pada Kelompok Format Surat jumlah anggota dari tingkat akademik atas hanya satu orang, dari tingkat akademik bawah juga satu orang, sementara dari tingkat akademik menengah ada lima orang.

Guru meminta setiap anggota kelompok baru terlebih dulu mendiskusikan aspek yang ditugaskan pada masing-masing kelompok, kemudian mengaplikasikan pemahaman mereka terhadap aspek yang telah dikaji tersebut pada contoh-contoh surat lamaran pekerjaan yang ditunjukkan guru sebelumnya. Selama proses diskusi berlangsung, guru berkeliling dari satu kelompok baru ke kelompok baru yang lain untuk melihat proses pelaksanaan diskusi dan keseriusan siswa dalam mengikuti pembelajaran. Namun, kegiatan guru sebatas menjaga keseriusan siswa dalam melaksanakan diskusi kelompok baru. Aspek yang ditekankan dalam Siklus I ini adalah kemandirian siswa dalam upaya memahami materi ajar yang diberikan. Sehingga, dalam Siklus I ini guru tidak secara intensif membimbing siswa dalam memahami aspek yang didiskusikan, melainkan sekedar memberikan jawaban seperlunya terhadap setiap pertanyaan siswa yang muncul. Siswa dibebaskan bereksplorasi untuk memperoleh pemahaman baru melalui diskusi kelompok baru tersebut.

Setelah setiap kelompok baru memperoleh kesepakatpahaman mengenai aspek surat resmi yang menjadi tanggung jawab mereka, guru meminta masing-masing siswa kembali ke kelompok awal. Selanjutnya, siswa diminta menyampaikan pemahamannya kepada teman anggota kelompok awal. Selama proses diskusi berlangsung guru berkeliling dari satu kelompok awal ke kelompok awal yang lain untuk mem- 
perhatikan kinerja siswa dalam diskusi kelompok awal tersebut sambil memperingatkan beberapa siswa yang tidak serius berdiskusi. Sebagaimana pada diskusi sebelumnya, diskusi kali ini juga ditekankan kemandirian siswa. Guru tidak mengarahkan pemahaman siswa terhadap materi yang didiskusikan karena diasumsikan wakil siswa dari kelompok baru telah mampu menyampaikan pemahamannya kepada temannya yang di kelompok awal. Sebagaimana disampaikan sebelumnya, setiap dari setiap kelompok awal diambil 2 siswa untuk mendalami aspek tertentu surat resmi dalam kelompok baru. Diharapkan 2 siswa tersebut dapat bekerjasama dengan baik dalam memahamkan aspek tersebut kepada teman-teman anggota kelompok awalnya.

Setelah diskusi kelompok awal ini selesai, dilakukan diskusi kelas. Pada saat diskusi kelas ini guru lebih berperan pengamat terhadap keseriusan, keresponsifan, dan kerjasama siswa. Peran sebagai problem solver dilakukan dalam kapasitas terbatas. Diharapkan, antara satu kelompok awal dengan kelompok awal yang lain dapat saling mengisi dan tukar informasi. Namun, dalam diskusi panel ini diketahui bahwa ternyata hanya siswa-siswa tertentu saja yang mampu mengemukakan pendapatnya berkenaan dengan aspek-aspek dalam surat resmi, sementara sebagian besar siswa yang lain cenderung pasif. Dan setelah guru menugasi mereka untuk menulis satu contoh surat resmi, sangat tampak bahwa surat resmi yang disusun siswa secara individual tersebut cenderung identik dengan surat yang dicontohkan guru, baik dari aspek format maupun bahasanya.

Hasil rekapitulasi nilai evaluasi produk akhir dalam Siklus I menunjukkan bahwa pada umumnya siswa dari tingkat akademik bawah memperoleh skor di bawah 50. Sepuluh skor terting- gi didominasi oleh siswa dari tingkat akademik tinggi. Sementara siswa dari tingkat akademik menengah menempati posisi medium, yaitu beberapa siswa memperoleh skor di bawah 50 dan sebagian besar yang lain memperoleh skor di atas 50. Skor terendah 31,5 diduduki oleh siswa dari kelompok bawah, sedangkan skor tertinggi 77,75 diduduki oleh siswa dari kelompok tinggi. Dari hasil perbandingan antara pengamatan terhadap aktivitas siswa selama pembelajaran dengan skornya dapat diketahui bahwa sebagian besar siswa yang memperoleh skor minim tersebut adalah siswa yang tidak aktif dalam diskusi asal maupun ahli. Sementara siswa dari tingkat akademik menengah maupun atas yang serius mengikuti pembelajaran pada umumnya mendapat skor di atas 50. Dengan demikian, dapat dikatakan bahwa pembelajaran pada Siklus I ini belum mencapai standar ketuntasan minimal yang ditetapkan. Berdasarkan hasil tersebut, maka dilakukanlah tindakan Siklus II sebagai upaya penyempurnaan Siklus I.

Secara umum, prosedur pelaksanaan tindakan Siklus II ini identik dengan prosedur pada Siklus I. Bedanya, dalam Siklus II ini keterlibatan guru pada kegiatan pembelajaran di kelas lebih ditingkatkan. Bimbingan guru terhadap siswa tetap hanya berupa arahan-arahan mengenai prosedur pembelajaran yang disampaikan pada awal kegiatan. Namun, kualitas arahan tersebut ditingkatkan. Guru menjelaskannya sampai detil dengan penekanan-penekanan yang mendalam pada hal-hal yang dianggap perlu mendapat perhatian siswa. Bahkan, secara halus guru juga memberi ancaman kepada siswa terkait dengan dampak yang terjadi apabila siswa tidak mlaksanakan diskusi secara sungguhsungguh. Bimbingan mengenai materi pembelajaran tetap dilakukan terbatas pada kelompok-kelompok yang memin- 
ta bantuan selama pelaksanaan diskusi tersebut.

Pembentukan kelompok ditentukan oleh guru dengan mempertimbangkan kemampuan akademik siswa, sedangkan pembentukan kelompok baru diserahkan sepenuhnya kepada siswa. Pada saat diskusi kelas (setelah diskusi kelompok baru dan kelompok awal) guru berperan sebagai moderator. Dengan demikian, guru dapat mengendalikan secara langsung situasi kelas pada saat diskusi kelas ini berlangsung. Siswa pun menjadi lebih aktif dalam berdiskusi. Setidaknya jumlah peserta diskusi yang pasif atau destruktif dapat ditekan dengan teguran langsung oleh moderator. Karena posisinya sebagai moderator, dalam diskuai kelas ini guru tidak menempatkan diri sebagai problem solver. Permasalahan yang muncul atau tidak terselesaikan dalam diskusi tidak diselesaikan oleh guru. Dengan kata lain, 'kedaulatan' diskusi ada di tangan siswa selaku peserta diskusi itu sendiri. Setelah kegiatan diskusi panel ini selesai dilakukan, guru memberi penegasan terhadap sejumlah pengetahuan baru tentang penulisan surat lamaran pekerjaan yang diperoleh siswa selama kegiatan pembelajaran. Penegasan guru diberikan dengan menyertakan ilustrasiilustrasi yang jelas. Guru juga memberikan pemecahan terhadap permasalahan kalimat efektif yang banyak dibicarakan dalam diskusi kelas. Siswa cukup antusias mengikuti penegasan guru ini.

Hasil rekapitulasi nilai evaluasi produk akhir dalam Siklus II menunjukkan bahwa sudah ada peningkatan pada seluruh siswa dari tingkat akademik bawah, tengah, maupun atas. Skor terendah 55,57 masih diduduki oleh siswa dari kelompok bawah, sedangkan skor tertinggi 78,5 juga masih diduduki oleh siswa dari kelompok tinggi. Tampak ada peningkatan skor yang cukup signifikan. Meski sepuluh nilai akhir tertinggi ma- sih didominasi oleh siswa dari tingkat akademik tinggi, dan siswa dari tingkat akademik menengah tetap menempati posisi medium, tetapi secara umum terdapat peningkatan kualitas pemahaman siswa terhadap surat resmi. Dari hasil perbandingan antara pengamatan terhadap aktivitas siswa selama pembelajaran dengan skornya dapat diketahui bahwa sebagian besar siswa yang memperoleh nilai minim tersebut adalah siswa yang tidak aktif dalam diskusi asal maupun ahli.

Dari paparan nilai evaluasi tersebut diketahui bahwa telah terjadi peningkatan kualitas hasil belajar siswa. Namun, proses pembelajaran Siklus II ini tidak berlangsung dengan baik. Ditengarai masih banyak siswa, tidak berdiskusi secara serius. Hal ini terutama terjadi saat pelaksanaan diskusi kelompok baru. Hal ini sejalan dengan kondisi yang terjadi pada Siklus I, yaitu kelompok yang dibentuk sendiri oleh siswa ternyata memunculkan adanya kelompok-kelompok dengan kemampuan akademik yang homogen. Siswa dengan tingkat akademik rendah cenderung berkelompok dengan siswa dengan tingkat akademik yang sama. Demikian halnya dengan siswa lain dengan tingkat akademik tengah dan atas. Akibatnya, sejumlah siswa yang tidak mengikuti aktivitas diskusi secara serius pada tahap kelompok baru tidak dapat menginformasikan hasil diskusinya kepada kelompok awalnya. Dan, hal ini berdampak pada kualitas pemahaman materi oleh siswa yang lain dalam kelompok awalnya. Akibatnya, peningkatan kualitas hasil belajar siswa tidak bisa maksimal. Dengan demikian, perlu dilakukan tindakan Siklus III sebagai upaya penyempurnaan Siklus II.

Dalam Siklus III ini keterlibatan guru pada kegiatan pembelajaran di kelas dipertahankan sama dengan keterlibatan dalam Siklus II. Guru memberikan 
arahan-arahan mengenai prosedur pembelajaran di awal kegiatan secara detil dan rinci dengan penekanan-penekanan yang mendalam pada hal-hal yang dianggap perlu mendapat perhatian siswa. Bahkan, secara halus guru juga memberi ancaman kepada siswa terkait dengan dampak yang terjadi apabila siswa tidak melaksanakan diskusi secara sungguhsungguh. Bimbingan mengenai materi pembelajaran tetap dilakukan terbatas pada kelompok-kelompok yang meminta bantuan selama pelaksanaan diskusi tersebut. Pembentukan kelompok asal dan kelompok ahli ditentukan oleh guru dengan mempertimbangkan kemampuan akademik dan keakraban sosial sehari-hari siswa. Pada saat diskusi kelas (setelah diskusi kelompok ahli dan kelompok asal) guru berperan sebagai moderator, dan ketika memberikan penegasan terhadap pengetahuan baru siswa guru berperan sebagai problem solver. Secara umum, pelaksanaan tindakan Siklus III ini identik dengan siklus-siklus sebelumnya.

Secara umum, dapat dikatakan bahwa pembelajaran dalam Siklus III ini berlangsung dalam kondisi tertib dan lancar. Hampir seluruh siswa bekerja dengan serius. Candaan dan gurauan siswa pun jauh berkurang dibanding dengan dua siklus sebelumnya. Memang masih ada satu dua siswa yang tidak serius, tetapi secara umum hal itu tidak berpengaruh signifikan terhadap pelaksanaan diskusi kelompok ini. Dan, hal ini berdampak pada kualitas hasil belajar surat resmi yang dicapai siswa. Hasil rekapitulasi nilai evaluasi produk akhir dalam Siklus III menunjukkan bahwa ada banyak peningkatan pada seluruh siswa dari tingkat akademik bawah, tengah, maupun atas. Skor terendah 66,75 masih diduduki oleh siswa dari kelompok bawah, sedangkan skor tertinggi 92,25 juga masih diduduki oleh siswa dari kelompok tinggi. Namun, peningkatan skor yang terjadi sangat signifikan. Tidak ditemui lagi skor akhir di bawah 50. Dengan demikian, dari segi hasil produksi, pembelajaran surat resmi dengan strategi kooperatif-kolaboratif ini dapat dikategorikan berhasil

Berdasarkan hasil tindakan Siklus I dapat ditarik suatu pengertian bahwa pembelajaran dengan strategi kooperatif-kolaboratif yang diterapkan dalam Siklus I ini belum benar-benar dipahami siswa. Dapat dikatakan bahwa upaya guru dalam menyampaikan prosedur pembelajaran belum efektif. Hal ini ditengarai oleh banyaknya yang siswa tidak melaksanakan diskusi secara serius, sehingga beberapa aspek dalam surat lamaran pekerjaan tidak dapat dipahamkan secara menyeluruh kepada setiap siswa dengan baik. Siswa belum menyadari bahwa pada hakikatnya prosedur pembelajaran dengan strategi kooperatif-kolaboratif merupakan suatu proses yang panjang dan terpadu. Pembelajaran dengan strategi tersebut dilaksanakan dalam dua kali pertemuan, dengan pertemuan kedua sebagai lanjutan dari pertemuan pertama. Kerumitan strategi tersebut terletak pada kegiatan pembentukan kelompok yang dilakukan hingga dua kali, yaitu kelompok awal dan kelompok baru. Pembentukan dua jenis kelompok ini menuntut siswa melakukan dua diskusi yang berbeda. Hal inilah yang membingungkan siswa. Banyak siswa memandang bahwa kedua diskusi ini tidak terkait satu sama lain. Mereka belum menyadari bahwa ketidakseriusannya dalam diskusi kelompok baru berdampak pada tidak terkuasainya suatu aspek tertentu, bukan saja oleh dirinya sendiri melainkan juga oleh teman-teman sekelompok awalnya. Dengan demikian, seharusnya guru tidak hanya memahamkan kepada siswa mengenai bagaimana prosedur pembelajaran tersebut dilakukan, melainkan lebih dari itu guru hendaknya 
mendeskripsikan kemungkinan yang terjadi apabila siswa tidak memperhatikan pembelajaran tersebut dengan baik.

Pembentukan kelompok awal dan kelompok baru diserahkan sepenuhnya kepada siswa dengan alasan faktor kepercayaan dan kemandirian siswa. Ternyata hal ini tidak sepenuhnya tepat. Kebebasan yang diberikan guru kepada siswa dalam menentukan anggota kelompok awal dan kelompok baru menjadikan siswa cenderung berkelompok (bergerombol) dengan teman sepermainannya. Mereka tidak mempertimbangkan perlunya pemerataan kemampuan akademik sebagai salah satu faktor penentu keberhasilan pembelajaran. Akibatnya, terjadi pengelompokan yang bersifat homogen, yaitu siswa berkemampuan akademik tinggi cenderung berkumpul dengan siswa lain yang juga berkemampuan akademik tinggi, siswa berkemampuan akademik menengah cenderung berkumpul dengan siswa lain yang juga berkemampuan akademik menengah, sementara siswa berkemampuan akademik rendah cenderung berkumpul dengan siswa lain yang juga berkemampuan akademik rendah. Meski pola pengelompokan yang demikian tidak berlaku mutlak pada semua kelompok, atau dengan kata lain dalam jumlah terbatas masih terjadi pembauran siswa dengan kemampuan akademik yang berbedabeda, pada kenyataannya pengelompokan dengan cara demikian mengakibatkan pembelajaran tidak berlangsung efektif. Banyak terjadi ketidakseriusan siswa dalam belajar. Seharusnya, untuk meminimalkan ketidakseriusan siswa dengan tetap menekankan kemandirian siswa dalam belajar, pembentukan kelompok awal dilakukan oleh guru kelas dengan mempertimbangkan pemerataan faktor kemampuan akademik siswa. Dasar pemikirannya, apabila kelompok awal diatur sedemikian rupa sehingga kemampuan akademik siswa merata maka konsentrasi belajar siswa dapat lebih ditingkatkan. Pengaturan pola pengelompokan pada kelompok awal dengan cara demikian ini diharapkan akan menekan kemungkinan terbentuknya kelompok baru yang homogen, tetapi tetap dapat mengupayakan terbentuknya kemandirian dan rasa tanggung jawab siswa dalam kegiatan pembelajaran.

Pada Siklus I dirancang guru tidak membimbing diskusi kelompok awal maupun kelompok baru, melainkan sekedar sebagai pengamat. Hanya pada saat tertentu saja guru ikut campur dalam kegiatan pembelajaran, yaitu saat memberikan instruksi dan ketika ada siswa yang bertanya karena ketidakpahamannya terhadap materi pembelajaran. Itu pun, informasi yang diberikan guru tidak maksimal. Siswa hanya dipancing dengan persoalan-persoalan lain yang sejenis sehingga diharapkan siswa bisa menemukan sendiri jawabannya. Hal ini dimaksudkan untuk memaksimalkan kemandirian dan tanggung jawab siswa, mengingat siswa yang diajar adalah siswa kelas 12 (kelas III SMA). Ternyata, kemandirian yang diharapkan belum dapat diberlakukan sepenuhnya bagi kelas yang dijadikan objek teliti. Pada aspek format surat dan ejaan dapat dikatakan relatif tidak ada permasalahan. Namun pada aspek pemilihan kata dan penyusunan kalimat efektif terjadi banyak kerancuan. Beberapa hal yang disepakati siswa baik dalam diskusi kelompok baru, kelompok awal, maupun diskusi kelas ternyata tidak benar. Dengan demikian, seharusnya guru perlu meningkatkan pembimbingannya pada setiap diskusi, bukan hanya dengan cara memberikan pancingan-pancingan persoalan lain yang sejenis, melainkan juga memberikan ilustrasi dan sedikit penjelasan yang dapat mengarahkan pemahaman siswa 
pada jawaban yang benar.

Pada saat diskusi kelas, guru memposisikan diri sebagai pengamat yang mengamati pelaksanan diskusi, sementara diskusi itu sendiri dimoderatori oleh siswa. Ternyata, hal ini kurang tepat. Suasana kelas yang sejak awal tidak konsentrsi penuh pada pelaksanaan diskusi (beberapa siswa tampak tidak serius mengikuti diskusi kelompok awal), menjadi lebih tidak terkendali dan sedikit gaduh pada saat diskusi kelas berlangsung. Siswa moderator tidak mampu mengendalikan suasana kelas yang sejak awal tidak terkondisi dengan baik. Sejumlah siswa tampak berbisikbisik atau tertawa-tawa (meski mereka segera diam saat guru memperhatikan kelakuan mereka, tapi kemudian mengulanginya lagi). Dalam hal ini, seharusnya peran guru lebih ditingkatkan. Guru bukan saja pengamat melainkan juga pengawas. Guru mengawasi siswa, yang berarti berimplikasi pada memberi teguran atau 'hukuman' kepada siswa yang tidak serius mengikuti pembelajaran.

Menurut pengamatan terhadap rekapitulasi nilai evaluasi produk akhir dalam Siklus I diketahui bahwa skor tinggi cenderung didominasi oleh siswa dengan tingkat akademik tinggi, sementara skor rendah tetap didominasi oleh siswa dengan tingkat akademik rendah. Berdasarkan hasil pengamatan lebih lanjut terhadap rekapitulasi nilai evaluasi produk akhir dalam Siklus I, ditengarai bahwa pada umunya skor rendah didominasi oleh siswa yang tidak aktif dalam pembelajaran, baik dari kelompok tingkat akademik rendah maupun menengah. Adapun skor tinggi didominasi oleh siswa yang aktif dalam pembelajaran, baik dari kelompok tingkat akademik tinggi maupun menengah. Dapat disimpulkan bahwa kemampuan akademik siswa dan kesungguhan siswa dalam mengikuti pembelajaran berkore- lasi positif dengan skor yang dicapai siswa. Pada beberapa siswa didapati bahwa kesungguhan dalam mengikuti pembelajaran saja yang berkorelasi positif dengan skor yang diperoleh siswa, sedangkan kemampuan akademiknya berkorelasi negatif dengan skor. Dengan demikian, seharusnya guru mampu meningkatkan keseriusan, keresponsifan, dan kerjasama siswa dalam pembelajaran. Sebab, ada indikasi bahwa kesungguhan dalam mengikuti pembelajaran berkorelasi positif lebih tinggi dengan pencapaian skor daripada kemampuan akademik siswa.

Pada Siklus II dilakukan sejumlah modifikasi, terutama terkait dengan peran guru dalam pembelajaran di kelas. Pada pelaksanaan pembelajaran Siklus II ini guru telah menyampaikan prosedur pembelajaran dengan strategi kooperatif-kolaboratif secara cukup jelas, tetapi ternyata hal tersebut belum benar-benar dipahami siswa. Dapat dikatakan bahwa upaya guru dalam menyampaikan prosedur pembelajaran belum sepenuhnya efektif. Hal ini ditengarai oleh banyaknya yang siswa tidak melaksanakan diskusi secara serius, sehingga beberapa aspek dalam surat resmi masih tidak dikuasai secara tuntas oleh setiap siswa dengan baik. Sebenarnya siswa telah menyadari bahwa pembelajaran pada pertemuan I dan II saling berhubungan dan berkelanjutan. Namun, kesadaran akan tanggung jawab bahwa pemahamannya berdampak pada pemahaman teman sekelompok awalnya ternyata masih rendah. Seharusnya guru tidak hanya memahamkan kepada siswa mengenai bagaimana prosedur pembelajaran tersebut dilakukan, melainkan lebih dari itu guru hendaknya mendeskripsikan secara detil kemungkinan-kemungkinan yang terjadi apabila siswa tidak memperhatikan pembelajaran tersebut dengan baik. Guru harus lebih rinci lagi menjelaskan prosedur ini kepada siswa, 
disertai deskripsi resiko jangka pendek dan jangka panjang apabila siswa tidak mampu mentransfer informasi materi pembelajaran secara tepat dan benar kepada siswa lain yang sekelompok awal.

Pada Siklus II ini, pembentukan kelompok awal dilakukan oleh guru denganmempertimbangkankeseimbangan komposisi kemampuan akademik siswa pada setiap kelompoknya. Alasannya, diharapkan upaya ini dapat meningkatkan pemahaman siswa terhadap aspekaspek surat lamaran pekerjaan yang diajarkan secara merata. Akan tetapi, tindakan ini tidak berhasil maksimal apabila pertimbangan kemampuan akademik siswa hanya dilakukan pada kelompok awal saja. Pembentukan kelompok baru diserahkan sepenuhnya kepada siswa dengan pertimbangan faktor kepercayaan dan kemandirian siswa. Ternyata kebebasan yang diberikan guru kepada siswa dalam menentukan anggota kelompok baru menjadikan siswa cenderung berkelompok (bergerombol) dengan teman sepermainannya, sehingga bersifat homogen dari segi kemampuan akademik. Namun, berdasarkan hasil diskusiantara peneliti dengan guru-guru pada saat refleksi terhadap pelaksanaan pembelajaran dalam Siklus 2, ditemukan bahwa ketidakefektifan proses dan hasil diskusi pada dua siklus pembelajaran yang telah dilaksanakan lebih dikarenakan oleh ketidakseriusan siswa dalam melaksanakan diskusi. Adapun ketidakseriusan siswa tersebut lebih disebabkan oleh berkumpulnya siswa berdasarkan keakraban sosial sehari-harinya. Karena keakraban tersebut, maka siswa-siswa yang memiliki dasar tidak serius dalam belajar (biasanya sifat ini dimiliki oleh siswa dengan tingkat kemampuan akademik bawah) akan cenderung tetap bergurau meski dalam kegiatan pembelajaran. Sementara siswa-siswa yang memiliki dasar serius dalam pembelajaran (biasanya sifat ini dimiliki oleh siswa dengan tingkat kemampuan akademik atas) akan cenderung tetap serius belajar. Kondisi semacam ini sangat tidak tepat diterapkan dalam pembelajaran dengan strategi kooperatif-kolaboratif, sebab akan ada kelompok siswa yang tidak kooperatif-kolaboratif dan akan ada kelompok siswa yang sangat kooperatif-kolaboratif. Penerapan strategi kooperatif-kolaboratif dalam pembelajaran ibarat sebuah sistem yang bulat dan utuh. Apabila satu komponen saja dari sistem tersebut tidak berfungsi, maka kerja seluruh sistem tersebut akan terganggu. Dalam hal ini, kelompok siswa yang tidak kooperatif-kolaboratif identik dengan sebuah komponen dalam suatu sistem yang tidak berfungsi. Keberadaannya sangat mengganggu jalannya sistem pembelajaran secara utuh, bahkan berpotensi menggagalkan pembelajaran tersebut sepenuhnya. Seharusnya, pembentukan kelompok awal maupun ahli sepenuhnya dilakukan oleh guru. Dasar pertimbangannya bukan pemerataan tingkat kemampuan akademik siswa pada masing-masing kelompok saja, melainkan juga memecah keakraban sosial sehari-hari siswa tersebut, dengan harapan siswa menjadi lebih berkonsentrasi dalam belajar. Perlu digarisbawahi bahwa kemandirian tidak selalu ditandai dengan pembentukan kelompok yang dilakukan sepenuhnya oleh siswa. Dalam hal ini, kemandirian lebih ditekankan pada kesempatan yang dimiliki siswa dalam bereksplorasi untuk memperluas wawasannya berkaitan dengan materi pembelajaran surat resmi.

Pada Siklus II dirancang guru tidak membimbing diskusi kelompok awal. Guru lebih memberikan sedikit perhatian lebih pada saat diskusi kelompok baru. Bila pada saat diskusi kelompok awal guru memposisikan diri sebagai pengawas, dalam diskusi kelompok baru guru memposisikan diri 
sebagai pengawas sekaligus pembimbing. Dalam perannya sebagai pengawas, selama proses diskusi berlangsung guru berkeliling dari satu kelompok baru ke kelompok baru yang lain untuk melihat proses pelaksanaan diskusi dan aktivitas siswa dalam mengikuti pembelajaran. Adapun dalam perannya sebagai pembimbing, guru memberikan ilustrasi dan sedikit penjelasan yang dapat mengarahkan pemahaman siswa pada jawaban yang benar. Dengan demikian, diharapkan siswa masih memiliki kesempatan bereksplorasi untuk memperoleh pemahaman baru melalui diskusi kelompok baru tersebut. Tindakan ini dianggap cukup efektif. Berdasarkan hasil evaluasi produk siswa diketahui bahwa ada peningkatan kemampuan dan pemahaman siswa terhadap surat lamaran pekerjaan.

Pada saat diskusi kelas, guru memposisikan diri bukan saja sebagai pengamat atau pengawas melainkan lebih dari itu sebagai moderator. Ternyata, tindakan ini sangat efektif. Suasana kelas menjadi lebih terkendali. Siswa pun menjadi lebih aktif dalam berdiskusi. Dalam kondisi ini, faktor segan sangat berperan dalam membentuk keseriusan siswa dalam belajar. Siswa yang semula tidak aktif dalam diskusi kelompok awal maupun kelompok baru, menjadi serius (meski dalam keadaan pasif) memperhatikan pemaparan teman-temannya. Setidaknya, meski tidak seperti yang diharapkan, keseriusan siswa dalam memperhatikan pemaparan temannya menjadikan wawasannya bertambah.

Menurut pengamatan terhadap rekapitulasi nilai evaluasi produk akhir dalam Siklus II diketahui bahwa skor tinggi masih cenderung didominasi oleh siswa dengan tingkat akademik tinggi, sementara skor rendah masih tetap didominasi oleh siswa dengan tingkat akademik rendah. Namun, secara umum telah ada peningkatan kualifikasi akademik siswa dalam penguasaannya terhadap surat lamaran perkerjaan. Diprediksikan, keseriusan siswa dalam diskusi kelas dan perhatian siswa terhadap penegasan guru dapat meningkatkan pemahaman siswa terhadap materi surat resmi.

Pada pelaksanaan pembelajaran Siklus III, upaya guru untuk memahamkan prosedur pembelajaran kepada siswa tidak hanya dilakukan dengan mendeskripsikan bagaimana pembelajaran itu dilaksanakan, melainkan juga memaparkan secara detil kemungkinan-kemungkinan yang terjadi apabila siswa tidak memperhatikan pembelajaran tersebut dengan baik. Bahkan, bila perlu guru juga menunjukkan resiko jangka pendek dan jangka panjang yang terjadi apabila siswa tidak mampu mentransfer informasi materi pembelajaran secara tepat dan benar kepada siswa lain yang sekelompok asal. Hal ini membuat siswa menjadi lebih hati-hati dalam bertingkah-laku selama pembelajaran berlangsung.

Pembentukan kelompok asal maupun kelompok ahli yang dilakukan oleh guru ternyata dapat mengatur keseimbangan kualitas setiap kelompok dengan mempertimbangkan pemerataan tingkat kualitas akademik siswa menurut aspek-aspek pembelajaran yang akan dibebankan kepada siswa. Pengaturan kesimbangan kualitas setiap kelompok juga dapat dilakukan dengan mempertimbangkan kualitas keakraban sosial sehari-hari siswa. Berdasarkan pengalaman, dapat diamati bahwa ternyata keakraban sosial tidak selalu dapat diberlakukan pada kegiatan diskusi dalam pembelajaran di kelas. Pada saat tertentu keakraban tersebut justru merugikan sehingga perlu dipecah agar siswa menjadi lebih serius dalam melaksanakan pembelajaran. 


\section{SIMPULAN}

Hasil penelitian ini membuktikan bahwa strategi kooperatif-kolaboratif dapat meningkatkan kemampuan menulis surat resmi siswa kelas III SMA bidang Bahasa. Untuk upaya memahamkan prosedur pembelajaran yang didasarkan pada strategi kooperatif-kolaboratif kepada siswa, tindakan guru tidak cukup hanya dilakukan dengan mendeskripsikan bagaimana pembelajaran itu dilaksanakan, melainkan juga harus dipaparkan secara detil kemungkinan-kemungkinan yang terjadi apabila siswa tidak memperhatikan pembelajaran tersebut dengan baik. Bahkan, bila perlu guru juga menunjukkan resiko jangka pendek dan jangka panjang yang terjadi apabila siswa tidak melaksanakan pembelajaran secara serius.

Pembentukan kelompok dalam pelaksanaan pembelajaran tidak dapat dilakukan sendiri oleh siswa, sebab hal ini akan memicu terbentuknya kelompok-kelompok yang homogen, baik berdasarkan tingkat kemampuan akademik siswa maupun tingkat keakraban sosial siswa. Karenanya, pembentukan kelompok sepenuhnya dilakukan oleh guru. Dengan demikian guru dapat mengatur keseimbangan kualitas setiap kelompok dengan mempertimbangkan pemerataan tingkat kualitas akademik siswa menurut aspek-aspek pembelajaran yang akan dibebankan kepada siswa. Pengaturan kesimbangan kualitas setiap kelompok juga dilakukan dengan mempertimbangkan kualitas keakraban sosial sehari-hari siswa, sebab pada kenyataannya keakraban sosial tidak selalu dapat diberlakukan pada kegiatan diskusi dalam pembelajaran di kelas. Pada saat tertentu keakraban tersebut justru merugikan sehingga perlu diatur sedemikian rupa sehingga siswa menjadi lebih serius dalam melaksanakan pembelajaran.
Dalam pelaksanaan pembelajaran di kelas, guru tidak perlu memberikan bimbingan kepada siswa pada saat diskusi kelompok awal. Bimbingan dan perhatian yang lebih perlu diberikan kepada siswa pada saat diskusi kelompok baru. Pada saat diskusi kelompok awal guru memposisikan diri sebagai pengawas, sedangkan dalam diskusi kelompok baru guru memposisikan diri sebagai pengawas sekaligus pembimbing. Dalam perannya sebagai pengawas, selama proses diskusi berlangsung guru berkeliling dari satu kelompok ke kelompok yang lain untuk melihat proses pelaksanaan diskusi dan aktivitas siswa dalam mengikuti pembelajaran. Adapun dalam perannya sebagai pembimbing, guru memberikan ilustrasi dan sedikit penjelasan yang dapat mengarahkan pemahaman siswa pada jawaban yang benar. Dengan demikian, siswa akan memiliki kesempatan bereksplorasi untuk memperoleh pemahaman baru melalui diskusi kelompok ahli tersebut.

Pada saat diskusi kelas, guru memposisikan diri sebagai moderator sekaligus, dalam proporsi terbatas, berperan sebagai problem solver. Dengan menempatkan diri sebagai moderator, situasi pembelajaran di kelas menjadi lebih terkendali, siswa pun menjadi lebih aktif dalam berdiskusi. Dengan menempatkan diri sebagai problem solver secara terbatas, guru tetap dapat membantu siswa menyelesaikan permasalahan-permasalahan yang muncul dalam diskusi dan mendesak untuk diulas. Namun, dengan peran terbatas tersebut, kemandirian siswa dalam memahami materi yang diajarkan cukup dapat diandalkan. Hal ini perlu dilakukan, mengingat siswa yang menerima pembelajaran ini adalah siswa kelas 12 (SMA kelas III). 
Pembelajaran dengan strategi kooperatif-kolaboratif seperti ini dapat diterapkan pada materi pelajaran yang lain, baik bahasa maupun sastra. Pada pembelajaran unsur intrinsik, misalnya, strategi ini juga dapat diterapkan dengan baik. Strategi kooperatif-kolaboratif juga tidak hanya dapat diterapkan pada siswa kelas III SMA saja. Kelas-kelas lain jenjang SMA bidang apa pun, bahkan jenjang SMP pun, juga dapat memanfaatkan strategi ini untuk melaksanakan pembelajaran bahasa dan sastra. Dapat dikatakan, bahwa selama penerapannya dilakukan secara tepat dan benar, maka materi apa pun dapat diajarkan dengan memanfaatkan strategi ini. Dengan strategi ini memberi kesempatan kepada siswa berlaku aktif untuk bekerja sama dalam kelompok. Selain merasa senang, siswa juga memiliki kesempatan untuk bereksplorasi dengan schemata yang dimilikinya dan mengaitkannya dengan materi yang dipelajarinya. Karenanya, penerapan strategi kooperatif kolaboratif dalam pembelajaran bahasa dan sastra, khususnya Indonesia, sangat disarankan.

\section{UCAPAN TRIMA KASIH}

Ucapan terima kasih disampaikan kepada Bapak/Ibu Guru Bahasa Indonesia dan para siswa kelas III Bidang Bahasa SMA Negeri Batu yang telah membantu pelaksanaan penelitian. Ucapan terima kasih juga disampaikan kepada mitra sejawat yang telah membantu kegiatan verifikasi dan triangulasi data dan hasil penelitian.

\section{DAFTAR PUSTAKA}

Badudu, J.S. 1995. "Bahasa Indonesia, Pengajaran Bahasa di Sekolah Dasar dan Kurikulum 1994". Makalah disajikan pada Seminar Sehari Bahasa dan Sastra Indonesia di hadapan guru-guru SD, SMP, SMA Kabupaten Garut pada tanggal 18 November 1995.

Burns, Anne. 1999. Collaborative Action Research for English Language Teacher. United Kingdom: Chambridge University Press.

Gipayana, Muhana. 2004. Pengajaran Literasi dan Penilaian Portofolio dalam Konteks Pembelajaran Menulis di SD. Dalam Jurnal Ilmu Pendidikan. LPTK-ISPI. Jilid 11 No. 1.

Kemmis, S. \& Taggart, M.C. 1992. The Action Research Planner. Victoria: Deakin University Press.

Suparno \& Yunus, M. 2002. Keterampilan Dasar Menulis. Jakarta: Pusat Penerbitan Universitas Terbuka.

Tomkins, Gail E., 1994. Teching Writing: Balancing Process and Product. NY: Macmillan College Publishing Company. 